\title{
Aikuisten medialukutaitoa selvitettiin Isossa-Britanniassa, entä Suomessa?
}

\author{
JUHA SUORANTA
}

Suomessa on viime vuosina keskusteltu vilkkaasti mediakasvatuksesta ja medialukutaidosta keskittyen ennen kaikkea lapsiin ja nuoriin. Isossa-Britanniassa on kuluvan vuoden keväällä valmistunut laaja selvitys eri-ikäisten medialukutaidoista ja median käytön valmiuksista. Selvityksen tilasi maan sähköistä mediaa valvova ja säätelevä, vuonna 2002 perustettu kansallinen viestintävirasto Ofcom (Office of Communications). Osana hanketta selvitettiin strukturoiduin käyntihaastatteluin reilun 3000:n 16-65-vuotiaan ja noin 500:n yli 65-vuotiaan median käyttöä.

Aikuisten medialukutaito määriteltiin kyvyksi käyttää erilaisia viestimiä, ymmärtää niiden toimintaperiaatteita ja luoda niillä kommunikaatiota erilaisissa ympäristöissä. Viestintäviraston virallisen kannan mukaan riittävä medialukutaito lisää aikuisväestön työmarkkinakelpoisuutta, työssä menestymistä ja yhteiskunnallisia vaikutusmahdollisuuksia. Selvityksen pääpaino oli digitaalisessa mediassa, eli digitelevision ja -radion sekä internetin ja kännykän käytössä. Raportti ei pidä sisällään tieteelliselle tutkimukselle tyypillisiä teoreettisesti perusteltuja tutkimuskysymyksiä, teoreettista viitekehystä, tulosten pohdintaa suhteessa muihin tutkimustuloksiin tai kokonaisuutta koskevia päätelmiä saati toimenpide-ehdotuksia.

Selvityksestä käy muun muassa ilmi, että televisio on pitänyt pintansa aikuisten suosituimpana mediavälineenä. Aikuiset ovat myös hyvin perillä televisio-ohjelmien ikärajoista ja sopivista katseluajoista sekä siitä, mikä kanava on kaupallinen ja mikä ei. Televisiota käytetään edelleen pääosin tavanomaiseen ohjelmien katseluun, mutta kolmisenkymmentä prosenttia digitaalikanavien katselijoista on käyttänyt televisionsa vuorovaikutteisia palveluja. Lähes neljällä viidestä vastaajasta on mahdollisuus kuunnella digitaalista radiota, mutta vain joka kolmas oivaltaa tämän.
Aikuiset etsivät internetistä pääasiassa tietoa, miltei kolme neljästä lähettää viikoittain sähköpostia. Internetin sisällöistä kannetaan huolta muuta mediaa enemmän. Erityisesti arastellaan henkilökohtaisten tietojen luovuttamista internetin kautta.

Internetin käyttäjien nettitaidot ovat yleensä hyvät, mutta joka kolmas ilmoittaa olevansa epävarma sen suhteen, kuinka mainokset tai virukset torjutaan. Epävarmuus koskee erityisesti mobiililaitteita, mutta myös tietokonetta.

Kännykät kuuluvat 16-24-vuotiaiden jokapäiväiseen maailmaan. Nuoremmat ovat omaksuneet mobiililaitteidensa monikäytön, vanhemmat tyytyvät soittamaan kännyköillään. Kaikissa ikäryhmissä on jo kuitenkin tavallista hyödyntää kännyköiden teksti- ja kuvatallennusominaisuuksia.

Ikä on merkittävä erojen tekijä median käytössä. Yli 65-vuotiaiden medialukutaito on heikompaa kuin nuorempien. Itse he kuitenkin sanovat, etteivät tarvitse uusia digitaalisia palveluja, eivätkä näin ollen käytäkään niitä. Raportissa ei puututa muihin mahdollisiin, esimerkiksi taloudellisesta tilanteesta tai sukupuolesta johtuviin eroihin aikuisten välillä tai pohdita niin sanottua digitaalista kuilua.

Etnisten ryhmien edustajat käyttävät digitaalista mediaa muita ryhmiä aktiivisemmin. Osaksi tämä liittyy ikään, he ovat valtaväestöön verraten nuorempia. Yli 45-vuotiaissa ero kääntyy kuitenkin toisin päin. Luottamus uutisiin on kaikissa ikäryhmissä alhainen, kuten mediaa koskevan säätelyn tai rahoitusmekanismien tuntemuskin.

Etenkin moni vanhemmista vastaajista toivoo saavansa oppia mediataitoja perheen piirissä, ystäviltä tai yksikseen eivätkä erikseen järjestetyssä koulutuksessa. 50:n ikävuoden jälkeen laitteiden käyttöopasten suosio oppimisen välineinä näyttää suorastaan romahtavan! Eniten halutaan oppia internetin käyttöä ja joka kolmas on 
kiinnostunut tietämään lisää myös muista digitaalisista laitteista ja palveluista.

Raportin ennusteet tulevaisuuden digitaalisesta kehityksestä eivät yllätä: internetin käytön, interaktiivisuuden ja käyttäjälähtöisten sisältöjen suosion povataan kasvavan.

Tämänkaltaiset kyselyihin perustuvat selvitykset ovat toki helppoja maaleja niin tekniselle, kyselyn tekemiseen ja metodologiaan liittyvälle kuin sisällölliselle kritiikille. Mutta kritiikissä on muistettava, että kyselyjä tehdään yleensä hallinnon tarpeisiin, jonka on mentaliteettinsa, tehtävänsä ja valitun tietoyhteiskuntapolitiikan nimissä tiedettävä, missä median digitalisoinnissa mennään.

Strukturoiduilla haastatteluilla ei päästä medialukutaidon lähteille eikä sen sosiaalisiin käytäntöihin: medialukutaito tulee määritellyksi (digitaalisten medialaitteiden käytön) määränä, asenteena tai arviona - ei arjen todellisina toimintavalmiuksina (toiminnallinen medialukutaito) tai poliittisena aloitteellisuutena (kriittinen medialukutaito). Jää myös epäselväksi, mitä medialukutaito tarkoittaa aikuisten elämässä, mihin se heidän toiminnassaan liittyy, mihin se voisi liittyä? Tai mitä tarkoittaa internetin käytön epävarmuus, onko se jopa turhaa tai liioiteltua? Pitäisikö aikuisille suunnatussa mediavalistuksessa korostaa uhkien lisäksi digitaalisen median tarjoamaa mahdollisuutta tiedon avoimuuteen tai vapaan pääsyn ideologiaa ja vapaiden ohjelmistojen kumouksellisuutta?

Huomionarvoista suomalaisen tietoyhteiskuntakehityksen kannalta on kuitenkin Ofcomin kaltaisen laitoksen olemassaolo ja sen piirissä viritelty laaja-alainen selvitys- ja tutkimustoiminta myös aikuisväestön piirissä. Suomessahan tämäntapaisia selvityksiä on tehty pääasiassa lasten ja nuorten parissa (esim. Suoranta \& Lehtimäki 2004). Toki aikuistenkin (painetun sanan) lukutaitoa on selvitetty (Linnakylä ym. 2000), muttei juuri medialukutaitoa tai digitaalista lukutaitoa. Vuosituhannen vaihteessa saadut tutkimushavainnot antavat kuitenkin osviittaa myös aikuisten medialukutaidoista. Valtaosa eli kaksi kolmesta lukee hyvin ja täyttää niin sanotut tietoyhteiskunnan jatkuvan oppimisen lukutaitovaatimukset. Parikymmentä prosenttia yltää tutkimuksen ylimmälle taitotasolle eli tietoyhteiskunnan asiantuntijatehtävissä vaadittavaan lukutaitoon. Neljäsosa aikuisista ymmärtää lukemansa, mutta tekstin tulkintataidot ovat puutteellisia ja luke- minen melko kritiikitöntä. Kolmasosa osaa lukea perinteisessä mielessä, mutta tämä ei tutkijoiden mukaan riitä tietoyhteiskunnassa vaadittavaksi lukutaidoksi. Noin kymmenesosan lukutaito on erittäin puutteellinen ja lisää syrjäytymisriskiä. Tämän lukutaidon kehittämiseen tarvitaan erityistoimia: tietojen ja taitojen vahvistamista, opiskeluhalun herättämistä ja yhteiskunnallisen aktiivisuuden lisäämistä. (Linnakylä ym. 2000.)

Sekä Ofcomin selvityksessä että Linnakylän ja kumppaneiden tutkimuksessa puhutaan medialukutaidosta, mutta tarkoitettaneen eri asioita. Ofcomin selvitys perustuu ihmisten antamiin vastauksiin, Linnakylän ym. tutkimus ennalta laadittuun asiantuntijamittaristoon. Tutkimuksellisesti Linnakylän ym. tutkimus on huomattavasti Ofcomin selvitystä perusteellisempi. Mediailmiöiden määrällistäminen on tarpeellista laajan kuvan saamiseksi ja uusien kysymysten herättämiseksi, lukutaitomittarit puolestaan vertailuasetelmien luomiseksi. Lisäksi tarvitaan laadullisia empiirisiä aineistoja, jotka kertovat digitaalisten laitteiden käyttökokemuksista ja laajemmin mediailmiöiden merkityksistä erilaissa toimintaympäristöissä. Lisäksi on tärkeää tehdä käsitteellistä selkeytystyötä medialukutaidon käsitteestä ja koota yhteen aikuisten mediakäytännöistä karttunutta tutkimustietoa, kuten mediatutkija Sonia Livingstone (2005) on tehnyt.

Keskushallinnollisesti mediakasvatusta edistävä toiminta hajautuu Suomessa usealle taholle, vaikka Opetushallitukselle se kai välittömimmin kuuluisi. Aloitteellisia ovat tähän asti olleet Oikeusministeriö ja Kansalaisvaikuttamisen politiikkaohjelma, jotka tilasivat vuonna 2005 selvityksen mediakasvatuksen kansallisista kehittämistarpeista (Kotilainen \& Sintonen 2005). Ja par'aikaa istuu opetusministerin nimeämä työryhmä suunnittelemassa toimenpideohjelmaa, jonka avulla edistetään mediataitoja ja -osaamista osana yleisiä kansalais- ja tietoyhteiskuntataitoja. Työryhmän painotus on lasten ja nuorten mediakasvatuskysymyksissä. Perustettiinpa Suomeen mediakasvatuksen seurakin vuonna 2005.

Nähtäväksi jää, miten aikuisten medialukutaito- ja mediakasvatustarpeet näkyvät tulevassa toimenpideohjelmassa ja mitä mediakasvatuksen seura saa aikaan. Toivottavaa on, että aikuisten medialukutaitoon kiinnitetään jatkossa tutkimuksellista ja toiminnallista huomiota.

Aikuiskasvatukseen aikuisten medialukutai- 
to liittyy paitsi alussa mainittujen mediankäyttökykyjen, työelämätaitojen ja kansalaisvaikuttamisen, myös vanhempainkasvatuksen kautta. Kuluneena kesänä Helsingin Sanomissa käydyssä mediakasvatuskeskustelussa korostettiin aikuisten vastuullisuutta median käyttöä koskevassa kasvatustehtävässä ja tietoutta medialaitteiden tekniikasta (Ahonen 2006) (viite 1). Lisäksi on kyettävä pohtimaan jo Platonin Valtiossa esittämää kysymystä: "Annammeko ilman muuta lasten kuunnella millaisia tarinoita tahansa, kenen hyvänsä sepittäminä, ja omaksua sieluunsa käsityksiä, jotka ovat enimmäkseen täysin päinvastaisia kuin ne joita heillä pitäisi mielestämme aikuisina olla?" Aikuisten mediakasvatuksessa tarvitaan pohdintaa hyvästä elämästä ja yhteiskunnasta sekä vaihtoehtoisten maailman mallien etsintää - esimerkiksi sellaisten, joissa kuvallisella väkivallalla ja muulla roskalla ei olisi markkinoita.

\section{Viite}

(1) Helsingin Sanomien 31.5.-18.7. julkaisemat puheenvuorot löytyvät osoitteesta http:// mediakasvatus.blogspot.com/2006/08/hesarinkeskustelu-mediakasvatuksesta.html.

\section{Lähteet}

Ahonen, Riitta (2006). Mediakasvatuksen on myös suojattava lasta. Helsingin Sanomat 13.7., C4.
Kotilainen, Sirkku \& Sintonen, Sara (toim.) (2005). Mediakasvatus 2005: Kansalliset kehittämistarpeet. Oikeusministeriön julkaisu 5/2005: http://www.om.fi/31548.htm

Linnakylä, Pirjo, Malin, Antero, Blomqvist, Irja \& Sulkunen, Sari (2000). Lukutaito työssä ja arjessa. Aikuisten kansainvälinen lukutaitotutkimus Suomessa. Koulutuksen tutkimuslaitos. http://www.jyu.fi/ktl/sials/ (5.7.2006)

Livingstone, Sonia (2005). Adult Media Literacy: A review of the research literature on behalf of Ofcom. http://www.ofcom.org.uk/ advice/media_literacy/medlitpub/medlitpubrss/?=87101 (4.7.2006)

Mediakasvatus. Wikipedia. http://fi.wikipedia. org/w/ndex.php?title=Mediakasvatus\&oldid $=1337486$ (5.7.2006)

Mediakasvatuksen seura: http:// www.ulapland.fi/?DeptID=20486 (5.7.2006)

Media Literacy Audit: Report on adult media literacy. (2006). (4.7.2006)

http://www.ofcom.org.uk/advice/ media_literacy/medlitpub/medlitpubrss/ medialit_audit/

Ofcom. http://www.ofcom.org.uk/advice/ media_literacy/medlitpub/

Platon (1981). Valtio. Teokset 4. Suom. M. Itkonen-Kaila. Otava.

Suoranta, Juha \& Lehtimäki, Hanna (2004). Children in the Information Society: The case of Finland. New York: Peter Lang. 